\title{
The Tension Between the Digital and the Actual in the Phenomenon of Dr. Tirta in Kompas.com
}

\author{
Nadya Afdholy* \\ Department of Language and \\ Literature Education \\ Universitas Negeri Surabaya \\ Surabaya, Indonesia \\ nadya.19002@mhs.unesa.ac.id \\ Setya Yuwana Sudikan \\ Department of Language and \\ Literature Education \\ Universitas Negeri Surabaya \\ Surabaya, Indonesia \\ setyayuwana@unesa.ac.id
}

\author{
Titik Indarti \\ Department of Language and \\ Literature Education \\ Universitas Negeri Surabaya \\ Surabaya, Indonesia \\ titikindarti@unesa.ac.id \\ Suhartono \\ Department of Language and \\ Literature Education \\ Universitas Negeri Surabaya \\ Surabaya, Indonesia \\ suhartono@unesa.ac.id
}

\author{
Darni \\ Department of Language and \\ Literature Education \\ Universitas Negeri Surabaya \\ Surabaya, Indonesia \\ darni@unesa.ac.id \\ Udjang Pairin \\ Department of Language and \\ Literature Education \\ Universitas Negeri Surabaya \\ Surabaya, Indonesia \\ udjangjw@unesa.ac.id
}

\begin{abstract}
The Covid-19 pandemic requires everyone to live in the excitement of the digital world. The critical quality of citizens is shown as the real quality of citizens who are immersed in demagogue-style misleading opinions. The process of digitalization emerges sudden popularity, that the figure of Tirta, who graduated from medical faculty and now run his digital shoe entrepreneurship, has more influential statement than a doctor who is serious about pursuing his job. The effect of Tirta's speech in the digital world is more impactful than the voice of experts. This study aims to 1) describe the presence of a new type of consensus in the digital world that was born during the pandemic, 2) re-analyze the demagogical potential in a democracy consisted in Kompas.com using the democratic perspective by Jacques Rancière. This research used Norman Fairclough's critical discourse analysis method. The data were taken from the online news entitled Cerita Dokter Tirta, Influencer yang Terjun Langsung Lindungi Tenaga Medis dari Covid-19 (The Story of Doctor Tirta, an Influencer Who Directly Involve to Protect Medical Workers from Covid-19). The data were analyzed by applying three-dimensional stages, namely micro, meso, and macro. The results show that Covid-19 has changed social relations only through digital media and produce a demagogic nuance. The society becomes disconnected from their social reality. Critical thinking is lost because of the unsuccessful dissensus. The digital world creates a new consensus that only represents social emotions.
\end{abstract}

\section{Keywords—demagogue, democracy, digital, Rancière}

\section{INTRODUCTION}

The Covid-19 phenomenon shows that society is in a digital nuance. This crisis presents a challenging paradox related to understanding digital society [1]. Society believes more in the digital than the actual so that all systems and human life relations become digital. Society is increasingly confirming that the digital is the original so that they are disconnected from their social reality. However, the termination of social relations is needed by society to achieve a new balance and prosperity [2]. People no longer see relationships based on mutual interactions because they do not meet face to face directly. Some who can still meet face to face is also prevented by masks that are used as an anti-contagious measure in the face of a pandemic [3]. Therefore, people believe more in digitalizing.

Digitalization conveyed information more quickly. What is happening around the world is conveyed in the fastest mode [4]. Paul Virilio's ideas about cybernetic knowledge reveal that digital culture changes and online communication changes more and more visually, the spread of material is getting more viral, information is getting more and more redundant at an accelerated rate [5]. Even though digitalization has entered all areas of life, people should see digitalization critically [6]. Nichols said that people prefer current results, which are in line with their views and beliefs based on the fact that we are digitally flooded with information [7]. It is in line with the factor why we are not more trusting to the experts for any information, but more immersed in demagogic misleading opinion. The less they know, the more they think they know many things [7]. The digital can makes society farther away from reality and critical thinking.

The digital world kills human interaction because people only believe in what is confirmed through digital. The digitalization process gave rise to the sudden popularity of doctor Tirta. Doctor Tirta or Tirta Mandira Hudhi is the founder of "Shoes and Care" [8]. The figure of Tirta, who graduated from the medical faculty and currently determined entrepreneurship has more influential statement than any other serious doctors in their job. People no longer care about the person's expertise because they trust more in the things they encounter digitally. This phenomenon is bad because Tirta's words in the digital world are more impactful and believed than the voice of experts. The relationship between expertise and society is equal to the relationship in a democracy that is built on trust [9]. When that trust collapses, then the expertise and society will be factions at war till causing democracy to move towards a death spiral. 
Previous studies that examined the Covid-19 phenomenon are as follows. Beaunoyer, Dupéré, \& Guitton [10] described the reciprocal impact of the Covid-19 crisis and digital inequalities that have the potential vulnerability to Covid- 19 . They contributed by proposing a layered strategy that focused on actionability and implementation at various structural levels in government, companies, and communities. Soudien [11] discussed the contemporary condition of Covid-19 concerning the ability to think about education in a more inclusive way. Covid-19 in this regard has changed the terms democracy, equality, social inclusion, and social justice to be better understood, and operated to bring to a new and better world. Soudien explored the possibilities regarding the new insights that would come in the future and how the system operated. Tiruneh, Baye, \& Dubi [12] explored the social media landscape and analyze it. The results showed that social media users used the platforms Facebook, Facebook Messenger, and Youtube as a means to link the status quo in the past and current Covid-19 and its socio-economic impact.

Based on previous studies, there is no any research that analyzed the Covid-19 phenomenon in online news from the democratic perspective considering that the mass media has a strategic role in form of public opinion. This study aims to 1) describe the presence of a new type of consensus in the digital world that was born during a pandemic era, 2) re-analyzed the demagogical potential of democracy contained in the online news Kompas.com using the democratic perspective by Jacques Rancière.

In Dissensus: On Politics and Aesthetics, Rancière [13] said the consensus is the machine of vision and interpretation that must completely set appearances right, put war and peace back in their place. All this goes to show that we are merely being asked to consent. The consensus is a social construction that develops in the society which is an agreement of the elites that forces the community to agree to them.

Rancière [14] said that consensus-oriented democratic practices have the opportunity to depoliticize conflict. The consensus makes serious effort to seek understanding (negotiation) which is bad for democracy. Understanding or negotiating, in this case, means congregating the logic of the majority to find an agreement that seems to embrace all interests. In The Politics of Aesthetics: The Distribution of the Sensible, Rancière said a policy appears and seems to have embraced the public [15], even though it only pleases certain groups.

In Disagreement: Politics and Philosophy which deals with political issues, Rancière [16] talks about democratic politics. The democracy is the impetus for producing new alternatives. Rancière [17] said that democracy is a process of disagreement. Disagree means rejecting an agreement that establishes consensus. The democratic politics is no longer a consensus in the sense of agreeing, but rather a dissensus in the sense of disagreeing. Social justice only be achieved by continuing to include the silenced voices, namely the voices of minorities. The democratic perspective was used to see the presence of a new kind of consensus in the digital world that was born during the Covid-19 pandemic.

\section{METHOD}

This research used Norman Fairclough's critical discourse analysis method with three-dimensional stages: text (micro), discursive practice (meso), and social praxis (macro) [18]. The first dimension in Fairclough's model is a description in which discourse is seen as a text (analytical text) which is related to the linguistic form of the text [19]. Limited text analysis alone is not sufficient to analyze a discourse, for it must explain the relationship between texts, processes, and socio-cultural structures. The second dimension is an interpretation that sees discourse as a discursive practice [20]. Discourse is seen as something that is produced which is mostly seen from the circulation of linguistic objects. The third is an explanation of how discourse is seen as a social practice (social analysis) that focuses on ideological effects and hegemonic processes in society.

The data were taken from the online news entitled Cerita Dokter Tirta, Influencer yang Terjun Langsung Lindungi Tenaga Medis dari Covid-19 (The Story of Doctor Tirta, an Influencer Who Directly Involve to Protect Medical Workers from Covid-19) published in the Kompas.com on March 29, 2020 [21]. The data collection technique was by reading and selecting topics that discuss Dr. Tirta in Bahasa which was later translated into English. The data were analyzed by applying three stages of the Fairclough dimension, namely micro, meso, and macro to find a new consensus in the digital world.

\section{RESULTS AND DISCUSSION}

This section presents three dimensions of Fairclough's critical discourse analysis, namely micro, meso, and macro, which are presented in the argumentation and description as a process to generate new types of consensus.

\section{A. Microstructure Analysis (Text)}

In reporting regards to Covid-19, Kompas.com involves a representative aspect that discusses how the figure of doctor Tirta is being highlighted in preaching which is displayed in the news text. The first sentence shows that Kompas.com chooses diction which has the potential to trigger conflict. The following is an analysis in terms of language in the news discourse about Dr. Tirta at Kompas.com.

(1) Tirta Mandira Hudhi atau yang lebih dikenal dengan Dokter Tirta merupakan seorang influencer sekaligus pengusaha muda yang cukup dikenal di Indonesia. Tirta Mandira Hudhi or better known as Doctor Tirta is an influencer as well as a young entrepreneur who is well known in Indonesia.

(2) Namun, gelar dokternya bukanlah hanya sekedar nama panggung yang ia digunakan di media sosial. However, his doctor's title is not just a stage name that he uses on social media.

(3) Meski telah terbilang sukses di dunia usaha, ternyata ia tak melupakan sumpah dokter yang pernah ia ikrarkan setelah lulus menempuh pendidikan kedokteran dulu.

Even though he has been considered successful in the business world, it turns out that he has not forgotten the doctor's oath that he took after graduating from medical education.

(4) "Jadi kan kalau dalam sumpah dokter kita harus melindungi teman sejawat kita dari depan, belakang, kanan, kiri entah apapun caranya," 
"So in the doctor's oath we have to protect our colleagues from the front, back, right, left no matter what,"

Based on script (1) and (2) Kompas.com shows the status of figures in the news by using the terms influencer and doctor. The terms influencer and doctor differ in their semantic meaning. Lexically, influencer means someone who can be influential as well as shows the status of the firstmentioned character. In the second sentence, the word 'ia' is used which refers to the status of another figure from the news, namely a doctor. Script (2) uses linguistic strategies that have a relationship with script (1). The causal sentence structure is characterized by the conjunction 'namun' which combines the causal in script (2) and (1). Script (3) explains how Kompas.com defended the influencer status of the Tirta figure who also did not forget the doctor's oath that had been made already. Furthermore, in script (4) Kompas.com quotes Tirta's statement which is a strategy to make news more attractive to its readers

(5) Tak bisa terjun langsung ke ruang perawatan karena sudah setahun ia tak praktik sebagai dokter, Tirta menempuh jalan lain untuk terlibat memerangi Covid19.

Unable to go directly to the treatment room because he has not practiced as a doctor for a year, Tirta has taken another path to get involved in fighting Covid19

(6) Memanfaatkan pengikutnya di dunia maya, Tirta menggerakkan orang untuk berdonasi membantu memenuhi kebutuhan alat pelindung diri (APD) rekanrekannya yang bertarung di garda terdepan.

Utilizing his followers in cyberspace, Tirta mobilizes people to donate to help meet the personal protective equipment (PPE) needs of his colleagues who are fighting at the forefront.

Script (5) explains how Kompas.com uses the pronoun 'ia' to express doubts about the status of doctor Tirta, who has not practiced as a doctor for a year but is involved in fighting Covid-19 in other ways. The 'jalan lain' dictation leads to other way, namely the strategy of action taken by the status of an 'influencer' who uses the 'nama panggung' of a 'dokter. Meanwhile, in script (6) Kompas.com mentions another bad strategy carried out by doctor figures who use virtual world followers by justifying in the following clause 'menggerakkan orang untuk berdonasi'.

(7) Bersama Dompet Duafa, pria ini juga ikut dalam kegiatan menyediakan seribu titik ruang penyemprotan disinfektan yang tersebar di tempattempat umum di Jakarta.

Together with Dompet Duafa, this man also participated in the activity of providing a thousand points of disinfectant spraying rooms scattered in public areas in Jakarta.

(8) Bahkan, ia juga berupaya memenuhi nutrisi tenaga kesehatan yang tengah berjibaku menghadapi pasienpasien Covid-19 yang jumlahnya terus bertambah.

In fact, he is also trying to fulfill the nutrition of health workers who are struggling with the growing number of Covid-19 patients.
(9) “... Karena beliau itu selalu mengajarkan, seorang dokter itu berjuang tidak harus jadi agen kuratif atau penyembuh, tapi juga bisa jadi agen edukasi, " ucap Tirta Seiring bersambut, ia bersama influencer lainnya diundang oleh BNPB untuk membantu pemerintah menyuarakan sekaligus mengedukasi masyarakat menghadapi Covid-19.

"... Because he always teaches, a doctor is struggling not to be a curative agent or a healer, but also an educational agent," said Tirta. Along with his welcome, he and other influencers were invited by $B N P B$ to help the government speak out as well as educate the public. facing Covid-19.

The argument logic for justification is compiled and systematized by Kompas.com on script (7) to (9). In script (7) Kompas.com positions itself as an audience who views the figure of doctor Tirta with his kindness in collaborating with the amil zakat institution in Indonesia which has the aim of alleviating poverty, namely Dompet Duafa and participating in providing a disinfectant room in Jakarta. Script (8) shows the existence of a causal sentence structure which is marked by the conjunction 'bahkan' which is part of the cause and effect of the script (8) and (7). Followed by script (9) which explains how Kompas.com quoted the influencer Tirta's statement as a logic of justification and defense of his status. The citation strategy is used by Kompas.com as a form of giving a positive image to influencer figures.

(10) Semua kegiatan itu ia publikasikan lewat media sosial yang ia miliki sambil terus mengedukasi masyarakat dengan ciri khasnya yakni "ngegas" karena dianggap bisa lebih didengar banyak orang.

He publishes all of these activities through his own social media while continuing to educate the public with his trademark "straightforward" because it is considered that many people can hear more.

Script (10) describes how Kompas.com uses the 'ngegas' diction to clarify Tirta's personality. Straightforward are words that are uttered with great emotion. Straightforward is a verb of action taken by influencer figures in influencing or educating the public as a reaction to the response to Covid-19.

\section{B. Mesostructure Analysis (Discourse Practice)}

Kompas.com is online media that leading in Indonesia founded in 1995. The philosophy behind the name Kompas shows its identity which can be used as a compass or a guideline by presenting actual and reliable news. In discursive practice, interpretation refers to the processing of discourse related to the production, distribution, and use of texts. The power of statements that encourage action is shown through the coherence of the interpreted text [18] so that people understand how to convey messages from a text. There are many parties in the text production process, namely editors, journalists, and editors. The discourse published by the Kompas.com had a lot of influence on Indonesian society. Kompas.com tries to position itself as an objective media and is not biased by various interests, especially in reporting about the viral Tirta figure during the Covid-19 pandemic.

\section{Macrostructure Analysis (Sociocultural Practice)}

Socio-cultural praxis emphasizes the social context that influences the emergence of discourse outside the media. The 
discourse is always intertwined with various levels both in the immediate situation (situational), in the institution/organization (institutional), and at the level of society (social level) [18]. At the situational level, Kompas.com produces texts that are following the context of the situation, namely the Covid-19 pandemic. Kompas.com highlighted the development, handling, and effects of Covid19 that occurred in society. Viral matters have become news to attract readers, including news about an influencer Tirta who went viral in the handling of Covid-19. At the institutional level, Kompas.com media wrote an accurate source that doctor Tirta that is an influencer indeed holds the title of doctor from the Faculty of Medicine, Gadjah Mada University, one of the leading universities in Indonesia. The mention of a large institution can also have a big influence on readers regarding the truth of the news so that the news can be said to be actual and reliable. At the social level, news about the viral influencers of medical graduates and calling themselves doctors is constructed based on social contexts. The relationship between the textual dimensions and the practical discourse that emphasizes siding with influencers Tirta is well imaged for the benefit of the media, indirectly eliminating the criticality of the audience. It illustrated that the conflict in Indonesia is not only about the prevention and cure of Covid-19 but also about the missing community criticality.

\section{The New Consensus in the Digital World and the Death of Expertise}

The mass media has a very strategic role in shaping public opinion. Likewise, during the Covid-19 pandemic, people believed more in digital information. Digital is not always better to believe without seeing the actual, even though there is good potential in the digital world such as people no longer seeing who is speaking but what is being offered so that whoever has the potential appears faster.

The phenomenon of Doctor Tirta, who was widely reported at the beginning of the spread of Covid-19 in Indonesia, is clear evidence that our society is under siege by the mass media. The digital has surrounded the real. The public trusts more the appeal from doctor Tirta who is no longer practicing as a doctor than the advice from doctors and the Minister of Health which is more legitimate. Doctor Tirta, who can only be met digitally, has defeated both the actual doctor and the Minister of Health. The public doesn't care whether the Tirta figure is a legitimate doctor and has a place of practice or not, but becomes enthusiastic when he is viral and popular.

Democracy for Rancière is an impetus for dissensus in the hope that there will be new alternatives in social life. The reality that occurred during the Covid-19 pandemic in Indonesia has further solidified consensus. The consensus on this is digital. With the viralness, doctor Tirta shows that he is the majority, while legitimate doctors are in the minority. This shows that digital is more desirable than actual. The majority do not need to last long, enough with certain times and moments he will form opinions and turn off other facts.

The consensus is still rampant in Indonesia because the minor cannot counter the major. The community unconsciously choose to be demagoguery because the digital ones surrounded quickly became the majority. The phenomenon of doctor Tirta confirms consensus, even though democracy wants a dissensus. The democracy is always stuck on consensus. Indonesian people are more spoiled with instant thing which kills critical thinking.

The digital makes us farther away from reality. Society's critical thinking method is increasingly lost because it is always digital, which is instant and fast-changing. The digital makes people only want to channel their passion for something that is considered to be representative. It so happened that doctors Tirta could reflect the majority vote to state their aspirations. Doctor Tirta's viral phenomenon shows that there is demagoguery in the Indonesian democratic process, especially in the Covid-19 situation. No alternative offer is available to provide dissensus.

The majority voice is bad because it is poor from criticism. People worship doctor Tirta because he is a doctor figure who can represent the needs of society, without them knowing that they worship those who are not experts. Doctor Tirta is the mark of a young, caring doctor, he represents the passions, interests, and expressions of society. If someone has a willingness but they do not do a critical analytical strategy so, it will appear a change to lose the expertise because people prefer to listen what they like rather than what they know.

The death of expertise can occur when experts no longer voice the public interest, instead, those who speak out are people who lack legitimacy in their expertise. It is feared that expertise will die not only because the community is less critical, but because they are unable to convey their expressions. Covid-19 widens the opportunity to generate a new demagogue and the death of expertise faster. This new majority model is provided virtually by Covid -19 .

\section{CONCLUSION}

The Covid-19 pandemic has made people believe more in the digital than the actual and increasingly shows its true qualities as demagogues who are compounded by virtual nuances. This happens because the digital as a whole represents the inner space of society. The media are expected to provide an alternative voice that is more critical and educated by providing a stage for legitimate experts and covering research-based matters so that people enter into the pedagogue space, not a demagogue.

\section{REFERENCES}

[1] M. Coeckelbergh, "The Postdigital in Pandemic Times: a Comment on the Covid-19 Crisis and its Political Epistemologies," Postdigital Sci. Educ., vol. 2, no. 3, pp. 547-550, Oct. 2020.

[2] L. Provenzi and E. Tronick, "The Power of Disconnection during the COVID-19 Emergency: From Isolation to Reparation," Psychol. Trauma Theory, Res. Pract. Policy, vol. 12, no. S1, pp. S252-S254, Aug. 2020.

[3] T. Greenhalgh, M. B. Schmid, T. Czypionka, D. Bassler, and L. Gruer, "Face Masks for the Public during the Covid-19 Crisis," BMJ, vol. 369, p. m1435, Apr. 2020.

[4] A. E. Chukwuyere, O. I. Nwanneka, C. C. Chukwudebelu, and E. B. Chidiebere, "Librarians' Use of Social Media in Disseminating Health Information on COVID-19," Int. J. Res. Rev., vol. 7, no. 7, pp. 443454, 2020.

[5] A. Kuntsman, "Socio-Political Figurations of Our Digital Everyday: Reflecting on Virilio's Notions of Dromology, Civilianisation of Military Technologies, and the Information Bomb," Media Theory, vol. 3, no. 2, pp. 133-144, 2019.

[6] N. Iivari, S. Sharma, and L. Ventä-Olkkonen, "Digital transformation of everyday life - How COVID-19 pandemic transformed the basic education of the young generation and why information management research should care?," Int. J. Inf. Manage., vol. 55, p. 102183, Dec. 2020. 
[7] M. Pulliam, "The Death of Expertise: The Campaign Against Established Knowledge and Why It Matters by Tom Nichols," $J$. Intellect. Free. Priv., vol. 2, no. 3-4, pp. 35-36, Apr. 2018.

[8] C. F. Kurnia, N. N. Yuwana, and A. P. Cahyani, "Pengembangan Jiwa Kewirausahaan di Kalangan Mahasiswa dengan Memanfaatkan Teknologi Digital," in UNEJ e-Proceeding, 2018, pp. 188-192.

[9] T. Nichols, The Death of Expertise: The Campaign Against Established Knowledge and Why it Matters. US: Oxford University Press, 2017.

[10] E. Beaunoyer, S. Dupéré, and M. J. Guitton, "COVID-19 and Digital Inequalities: Reciprocal Impacts and Mitigation Strategies," Comput. Human Behav., vol. 106424, pp. 1-9, Oct. 2020.

[11] C. Soudien, "Systemic Shock: How Covid-19 Exposes Our Learning Challenges in Education," South. African Rev. Educ., vol. 26, no. 1, pp. 6-19, 2020.

[12] D. Tiruneh, G. Baye, and Y. B. Dubi, "A Critical Discourse Analysis of COVID-19 in Ethiopia: Rethinking the Past and Defining the Present," J. Lang. Lit., vol. 20, no. 2, p. 318, Oct. 2020.

[13] J. Rancière, "Dissensus: On Politics and Aesthetics." Bloomsbury Publishing, London, 2010.
[14] L. Rossini and I. Bianchi, "Negotiating (re)Appropriation Practices amid Crisis and Austerity," Int. Plan. Stud., vol. 25, no. 1, pp. 100121, Jan. 2020.

[15] J. Rancière, The Politics of Aesthetics: The Distribution of the Sensible. London: Continuum, 2004.

[16] J. Rancière, Disagreement: Politics and Philosophy. US: University of Minnesota Press, 1999.

[17] C. Rhodes, I. Munro, T. Thanem, and A. Pullen, "Dissensus! Radical Democracy and Business Ethics," J. Bus. Ethics, vol. 164, no. 4, pp. 627-632, Jul. 2020.

[18] J. Haryatmoko, "Critical Discourse Analysis (Analisis Wacana Kritis) Landasan Teori, Metodologi, dan Penerapan.” Rajawali Press, Jakarta, 2016.

[19] N. Fairclough, Analysing Discourse: Textual Analysis for Social Research. London: Routledge, 2003.

[20] N. Fairclough, Discourse and Social Change. Cambridge: Polity Press, 1992.

[21] J. R. Azhari, "Cerita Dokter Tirta, Influencer yang Terjun Langsung Lindungi Tenaga Medis dari Covid-19," Mar-. [Online]. Available: https://megapolitan.kompas.com/read/2020/03/29/12163261/ceritadokter-tirta-influencer-yang-terjun-langsung-lindungi-tenaga-medis. 